\title{
Contemporary Photography Practice: Expanded Methodology and Critical Ways of Thinking
}

Rodrigo Hill, originally from Porto Alegre, Brazil currently living in Whaingaroa Raglan Aotearoa New Zealand. Rodrigo's photography practice focuses on people, place and its intrinsic relationships. Explorations of place and its surrounding dynamics have always been the core of Rodrigo's work. Rodrigo's research interests are rooted at the intersection of lens-based and curatorial apparochaes in which photography plays the role of representing layered place-imaginaries. Rodrigo's photography practice explores the use of imagery to create meanings and understandings of place followed by curatorial practices towards photobooks and gallery installations. Rodrigo holds a PhD from the University of Waikato Faculty of Arts and Social Sciences. <rdrgohill@gmail.com> ORCID: 0000-0003-3943-0393
Abstract Contemporary photographic practice has advanced into a broad territory of representational flux and modalities. This is a stimulating moment for lens-based practitioners and practice-led researchers willing to explore expanded modes of academic inquiry connected the medium of photography. In this article I draw key methodological insights from my Practice-led PhD project Place Imaginaries: Photography and Place-making at Te Awa River Ride. I explore relationships between photography and place-making and how photography is embedded within place-making processes. As a photographer and artist I developed a methodology based on photography practice and the iteration of curated bodies of photographic work. Te Awa River Ride is my research locale, a shared pathway that edges the banks of the Waikato River in the central North Island of Aotearoa New Zealand. Photography practice or lens-based practice is located at the core of my methodological research approaches; a space, which informs both theoretical and practice-led research developments en route to expanded critical modes of academic inquiry.

Keywords Lens-based image, Methodology, Photography, Place-making, Practice-led research. 


\section{Prática Fotográfica Contemporanea: Metodologia Expandida e Formas Críticas do Pensamento}

Resumo A prática fotográfica contemporânea avançou em um amplo território de fluxos e modalidades representacionais. Este é um momento estimulante para artistas que trabalham com imagens baseadas em lentes e pesquisadores orientados pela prática dispostos a explorar modos expandidos de investigação acadêmica conectados ao meio da fotografia. Neste artigo, extraio ideias metodológicas importantes do projeto de doutorado, Place Imaginaries: Photography and Place-making at Te Awa River Ride. Eu exploro as relações entre a fotografia e a criação de lugares e como a fotografia está inserida nesses processos. Como fotógrafo e artista, desenvolvi uma metodologia baseada na prática fotográfica e na iteração de trabalhos de curadoria fotográficos. Te Awa River Ride é o local de pesquisa, um caminho que margeia o rio Waikato, na parte central da Ilha Norte da Aotearoa Nova Zelândia. A prática fotográfica ou prática baseada em lentes está localizada no centro de abordagens metodológicas de pesquisa com fotografia; um espaço que informa desenvolvimentos de pesquisa teóricos e práticos a caminho de modos críticos de investigação acadêmica.

Palavras chave Imagens baseadas em lente, Fotografia, Construção de lugar, Metodologia, Pesquisa orientada pela prática.

Práctica fotográfica contemporánea: metodología ampliada y formas de pensamiento críticas

Resumen La práctica fotográfica contemporánea ha avanzado en un amplio territorio de flujos y modalidades representacionales. Este es un momento emocionante para los artistas que trabajan con imágenes basadas en lentes e investigadores orientados a la práctica que desean explorar modos ampliados de investigación académica conectados al medio de la fotografía. En este artículo, extraigo importantes ideas metodológicas del proyecto de doctorado, Place Imaginaries: Photography and Place-making at Te Awa River Ride. Exploro la relación entre la fotografía y la creación de lugares y cómo la fotografía se inserta en estos procesos. Como fotógrafo y artista, desarrollé una metodología basada en la práctica fotográfica y la iteración de trabajos de curación fotográfica. Te Awa River Ride es el sitio de investigación, un camino que bordea el río Waikato, en la parte central de la Isla Norte de Aotearoa, Nueva Zelanda. La práctica fotográfica o práctica basada en lentes se ubica en el centro de los enfoques metodológicos de la investigación con fotografía; un espacio que informa los desarrollos teóricos y prácticos de la investigación en el camino hacia modos críticos de investigación académica.

Palabras clave Imágenes basadas en lentes, Fotografía, Construcción de lugares, Metodología, Investigación orientada a la práctica. 


\section{Introduction}

In this article I draw key methodological ideas from my Practice-led PhD project Place Imaginaries: Photography and Place-making at Te Awa River Ride (Hill, 2019). My focus is on particular aspects of my photography practice and methodology presented at the Auckland University of Technology Link Symposium 2020 in Aotearoa New Zealand (Hill, 2020). I explored the intersection of photography and place-making and how photography is embedded within ways of knowing, understanding and making places. As a photographer and artist I developed a methodology based on photography practice and the iteration of four bodies of photographic work formatted into different curatorial platforms. I start with a brief introduction to my research place, the Waikato River and Te Awa River Ride. This will be followed by broader discussions on practice-led research approaches and contemporary photography practice, the conceptual notion of place imaginaries and resulting iterative methodology. My goal is to demonstrate and discuss my research methodology as a valid practice-led pathway to academic inquiry based on contemporary lens-based strategies.

Contemporary photographic practice has evolved into an expanded field of possibilities and representational modalities. In parallel the depth and layering of places offers stimulating challenges to researchers and artists whom are willing to creatively explore notions of place as research sites and topics. Te Awa River Ride is my research locale, a shared pathway that edges the banks of the Waikato River from Ngāruawāhia to Cambridge, in the central North Island of Aotearoa New Zealand. I explore notions of place and place-making by presenting a number of curatorial iterative products that had a final moment as an installation of photographs titled South of the Rising Sun. I offer this photography installation as a creative milestone which resulted from a methodology of iteration and artistic expression. In this article I explain my research methodology, arguing the ways contemporary photography practice and lens-based approaches informs methodological research developments en route to critical ways of thinking. 


\section{Waikato River and Te Awa River Ride}

Fig 1. 2017 Tūrangawaewae Marae Annual Regatta. Photographed with permission from Tūrangawaewae Marae

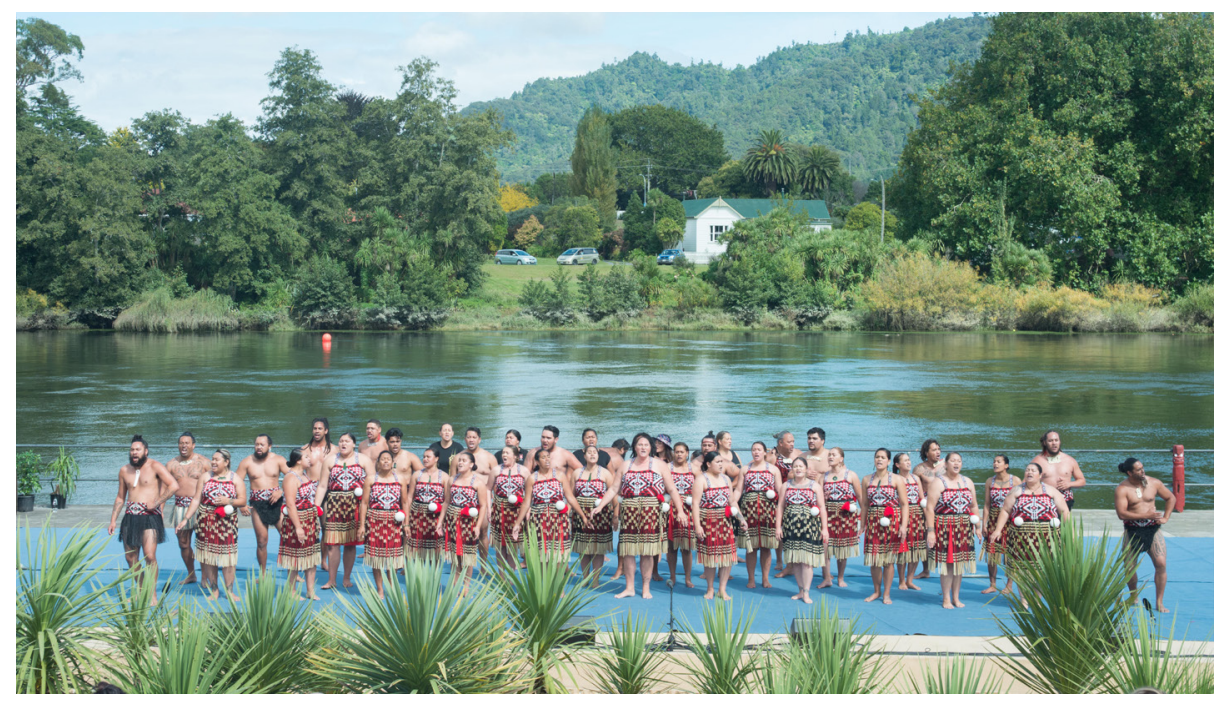

Te Awa River Ride is located within the broader territory of many Waikato Tainui iwi (tribe), hapū (sub-tribe) and whānau (extended family) that inhabited the area between Huka Falls and Te Puuaha o Waikato, including the Waikato region (Waikato Raupatu Lands Trust, 2008). The tribes that lived in the Waikato Valley were essentially river people who regarded the Waikato River as great spiritual sustenance as well as a source of food and transportation network (King, 2013). As outlined in the Waikato Raupatu River Settlement information package (2008), "to Waikato-Tainui, the Waikato River is a tuupuna (ancestor) which has mana (prestige) and in turn represents the mana and mauri (life force) of the tribe" (p. 27). The Waikato River therefore is essential for the establishment and maintenance of Māori identity and chiefly power as Muru-Lanning (2016) highlights: "When referring to the Waikato River as a tupuna awa, I suggest that Waikato Māori are in fact demonstrating that they view the river holistically and as an intrinsic part of their culture, politics, economy and identity". (p. 153)

Land and place are therefore paramount to Māori (King \& Roa, 2015) and the surrounding relationships between tangata and whenua (Fisher, 2016). Researcher Martin Fisher highlights the importance of land to Māori and the many connections and place-making developments between people, land and place (2016a). Fisher locates in a Māori proverb the ways tangata and whenua are intrinsically connected: "Te toto o te tangata he kai, te oranga o te tangata he whenua" ("The lifeblood of a person is derived from food; the livelihood of a people depends on land") (p. 19). These ideas around the ways Māori, and specifically Waikato Tainui, perceive and make place are useful to understand subsequent place-making developments 
within the Waikato Valley and Te Awa River Ride. The geographical area where Te Awa River Ride is located comprises Waikato Tainui land territories confiscated during the wars in the 1860s. Some of the land territories were later returned to Waikato Tainui after the Waikato Raupatu Claims Settlement Act in 1995 (Boast \& Hill, 2009; Waikato Raupatu Lands Trust, 2008). Within this scenario, Te Awa River Ride becomes a place intersected by crucial Waikato and Aotearoa historical layers and views.

\section{Practice-Led/Creative Practice Research}

As a starting point, I propose a link between my photography practice and practice-led research in general or research with arts-based components/creative practice research. My goal is to contextualise contemporary creative practice research within the possibilities of broader academic research approaches (Butt, 2017).

Patricia Leavy (2014), a creative practice activist, believes that "arts-based researchers are not "discovering" new research tools, they are carving them" (p. 3). Leavy proposes a relationship between shape and the forms of academic work, and how the form shapes the content. Leavy argues that arts-based researchers "see and build in different shapes" (p. 3). In this context, my photography practice at Te Awa River Ride is my attempt to carve novel approaches and research methods, pursuing a methodological model that informs my research frameworks and curatorial products. In addition, I am aware of the necessity to shape a model that incorporates a range of elements from my photography practice. This model integrates research frameworks, the affordances of different kinds of photographic apparatuses, as well as my own aesthetic sensibilities to construct my images. This model consists of photography practice as a complex set of strategies. I use photography as a starting and ending point. I draw on a wide range of conventions in the medium en route to novel ways of knowledge construction. This is no straight route and it comes with no guide as I draw on multiple disciplines aiming to intersect ideas and methods into a dynamic methodological organism. In the next section I will contextualize photography practice within qualitative research frameworks.

I position myself as a qualitative researcher, beginning with a constructionist epistemology and interpretive research paradigm. I therefore reject the idea of photographs as objective representations. On the contrary, I understand photographic images as catalysers for the construction of multiple meanings. In the next section I will discuss the notion of the term place imaginaries and its implications. 


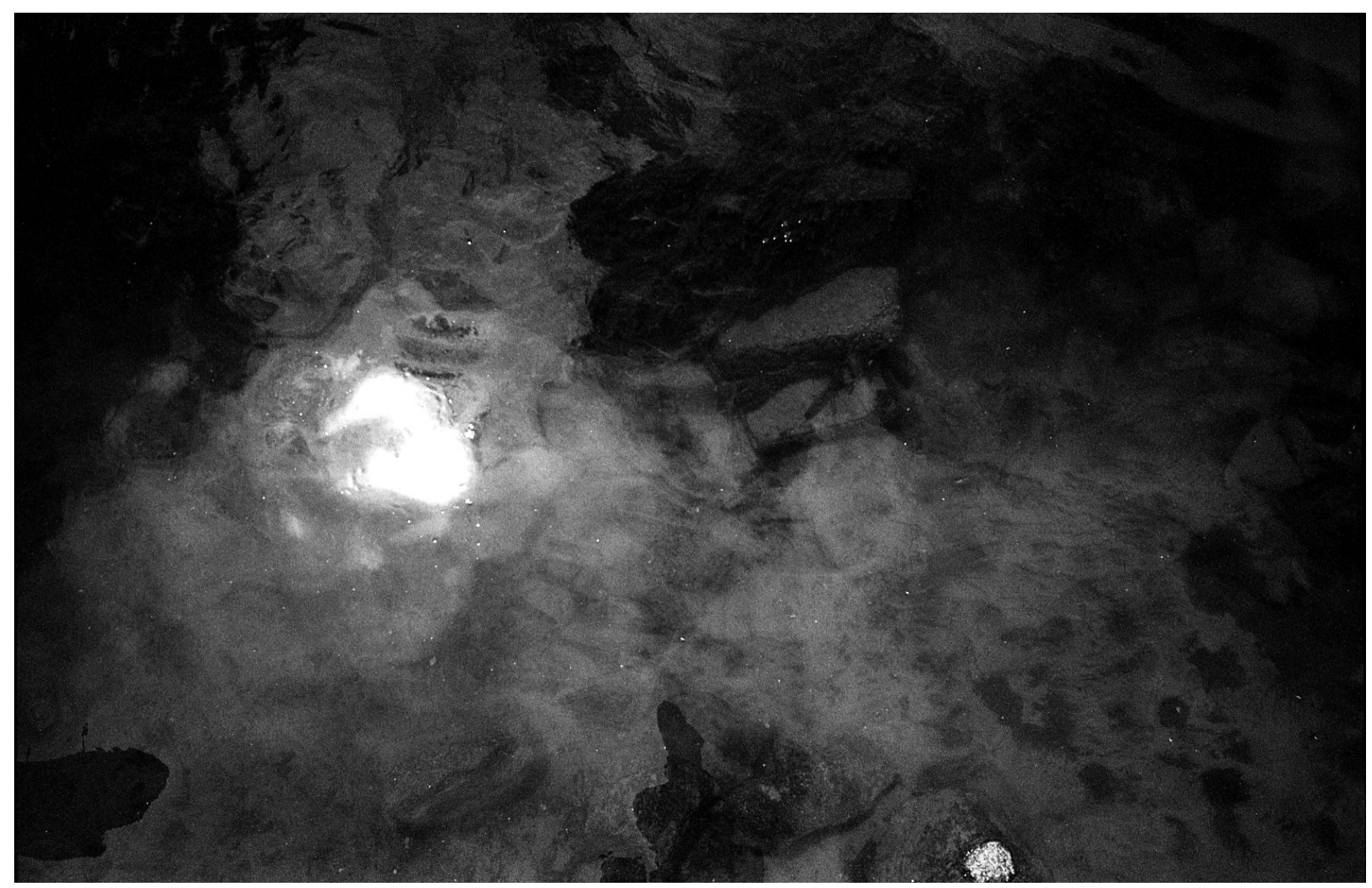

Fig 2. Light reflections on

the Waikato River.

\section{Place imaginaries}

Place imaginaries (Hill, 2019) is a multifaceted concept that consists of a free flowing imagery field between the actual and the virtually perceived. I draw ideas from multiple authors in order to illuminate my concepts of place-making and place imaginaries (Bergson, 1911, 2001; Deleuze, 1988, 1989; Deleuze \& Guattari, 1994; Egert, 2016; Massey et al., 2007; Sonn et al., 2015). This model has been carved from a range of disciplines and qualitative literature review. It is not my goal here to discuss the depths of this theoretical model, but simply highlight its importance as a creative catalyser for my photography practice. The term 'imaginaries' is a way to describe visual possibilities, constructions and psychological visual responses to my experiences at Te Awa River Ride. This process is intrinsically connected to subjective processes of perceiving and understanding the world and subsequently the ways I photographically explore dimensions of cultural perception, affect and memory. I argue that the expansion of my 
photography practice to encompass a project of imaginary constructions of place is a useful route to ground the multi modal aspect of my practice, and strongly linked with postmodernist approaches to photography. Within this context my photography practice is therefore liberated from objective views, opening up expanded representational possibilities all based on the idea of constructions at times composed, posed and collaborative (Köhler, 1989). Next I will discuss my photography practice and iterative outputting of creative milestones.

\section{Photography Practice and Creative Milestones: A Methodology of Iteration}

As introduced earlier my photography practice aimed at the construction of four creative milestones or curatorial products. These developments were highly iterative and followed a progression of methods and conventions connected to contemporary lens-based approaches to photography. I will focus more on the actual methodological flow rather then specific methods applied. This will cover the introduction of four creative milestones, highlighting particular aspects of each stage. The outputting of creative milestones and iterative processes can be argued as part of or simply as photography practice.

Creative milestones were curatorial research products. They marked points within the overall research time frame. Each creative milestone involved the construction of a photo narrative. In the first creative milestone, I used the photobook as a narrative platform. The second creative milestone involved the construction of a digital sequence of black and white images. The third and fourth creative milestones marked further explorations around sequencing, photo montage and photo narrative within photography installation platforms. So, essentially, a creative milestone, within the parameters of my research, was a curated photo narrative product, structured within particular conventions and aimed at the argumentation of particular ideas. This process was useful to the development of my methodology and the subsequent coalescing between my theoretical frameworks and photography practice. The iteration of creative milestones covered experimentations with possibilities and techniques connected to multimodal representational systems. These were informed by sequencing and curation of imagery all aimed at particular curatorial platforms.

Each creative milestone marked the end of a stage within an iterative process and the beginning of the next one. For example, my creative milestone two was a digital-based black and white photographic sequence. The actual visual product or milestone is the final moment of a particular creative stage in which I have explored a particular set of strategies and methods in order to achieve a particular creative result. The creative milestone is one of many possibilities, a way to curate images into a cohesive 
curatorial prouct. In this sense, the creative milestone could be more about the iteration of curating, sequencing and assembling images within particular conventions rather than the actual techniques and methods used within a given creative time frame. In parallel, my photographic production at Te Awa River Ride steadily advanced and within this progression I tested and implemented new methods while building on some already established strategies. However, it is possible to argue that at each creative milestone time frame a particular set of methods has been tested and implemented. This is clearer in my creative milestone two in which I only focused on the medium of black and white film photography and its representational possibilities. The creative milestones were, most importantly, ways of working through particular collections of images informed by conventional ways of imagery juxtaposition and displaying.

Riding the River Ride (creative milestone one) and Let Light Create Imaginary Spaces (creative milestone two) share similar curatorial approaches where I produced and curated a group of images towards a specific creative product. The actual photographic style and techniques were different and yet aimed at the construction of a photo narrative. Riding the River Ride was my first attempt to compile a number of photographs, maps and words into a particular narrative platform, namely the photobook. Contrary to Riding the River Ride, Let Light Create Imaginary Spaces has been entirely conceived and presented digitally. However, I argue that the digital formatting and compilation of the images may also be used for the creation of a photobook where images are similarly sequenced in a particular order.

Creative milestones three and four were curated and informed by the spatial nature of gallery installations (Bishop, 2005; Celant, 1996; De Oliveira et al., 2006), moving away from two dimensional platforms to more considerate use of space to help represent place. The gallery space also provided more possibilities to explore scale, juxtaposition and sequencing of images that differ from my previous chosen curatorial platforms. I consider my creative milestone \#3 Stimuli a very useful curatorial exercise where I was able to test a number of sequential compiling strategies in order to compress multiple images into a cohesive visual statement. As an installation Stimuli provided an alternative way for audiences to engage with photographic sequences (more commonly bounded to photobooks), moving into and around the body of images. Figure 3 below shows the final installation on the wall at Demo Space Gallery Tāmaki Makaurau Auckland 2017. 

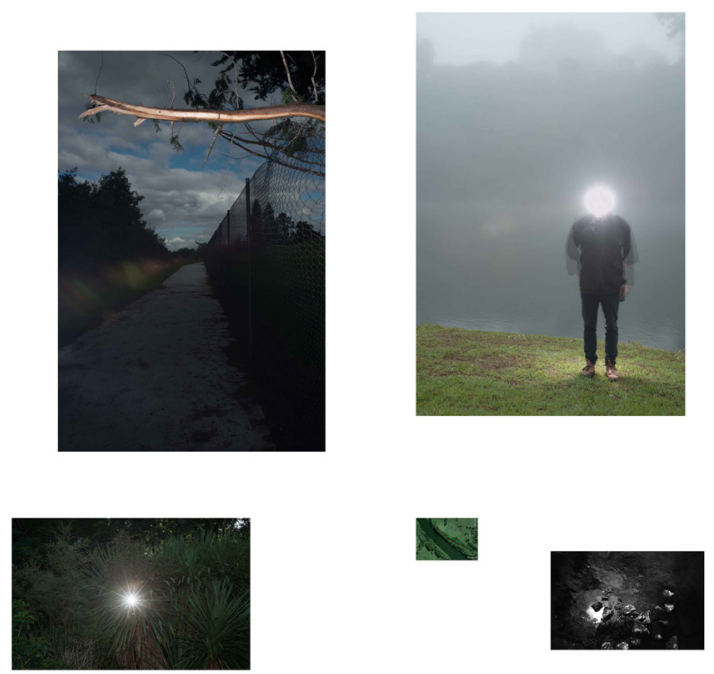
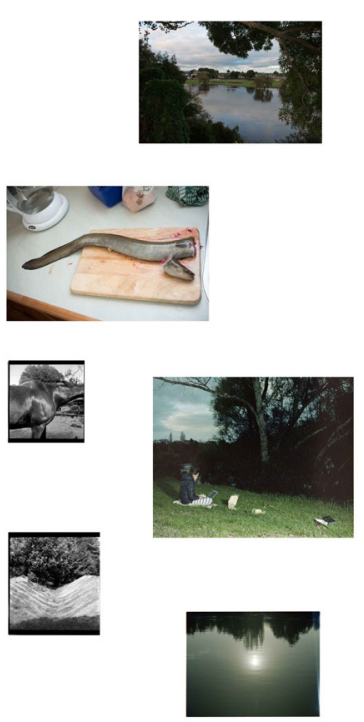

Fig 3. Stimuli installation

Fig 4. Detail of South of the Rising Sun installation, 2018, Ramp Gallery, Hamilton, NZ.
South of the Rising Sun was my final creative milestone and a progression from Stimuli. I understand South of the Rising Sun as an expanded curatorial project, comprising the curation and sequencing of two bodies of photographic works, one black and white and the other colour, that together function as a visual installation of place imaginaries. South of the Rising Sun functions as a system of meanings where photographs "may be seen in terms which are simultaneously personal, political, economic, dramatic, everyday and historic" (Berger, 1980, p. 63). The installation is not a final response to place-making or an absolute representation of the Waikato river and Te Awa River Ride. On the contrary, South of the Rising Sun represents a version, and a iterative way to photographically coalesce multiple place imaginaries. Figure four below shows a sequential section of the colour works from South of the Rising Sun.
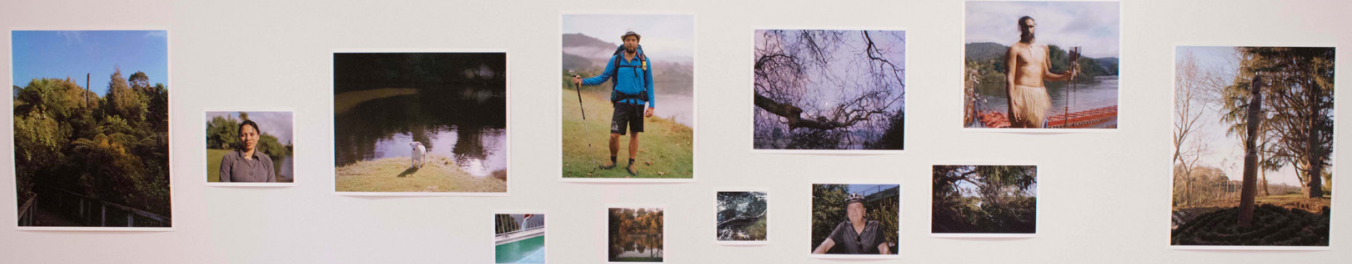
The image below represents the ways I explored the visual motifs of water, ecology and place in order to actualise particular place imaginaries connected to the Waikato River and Valley. This image became a rich source of inspiration and representation of key conceptual parameters. As an artist it is very satisfying to arrive at a valid creative product resulted from incessant iterations and obsessive creative quest.

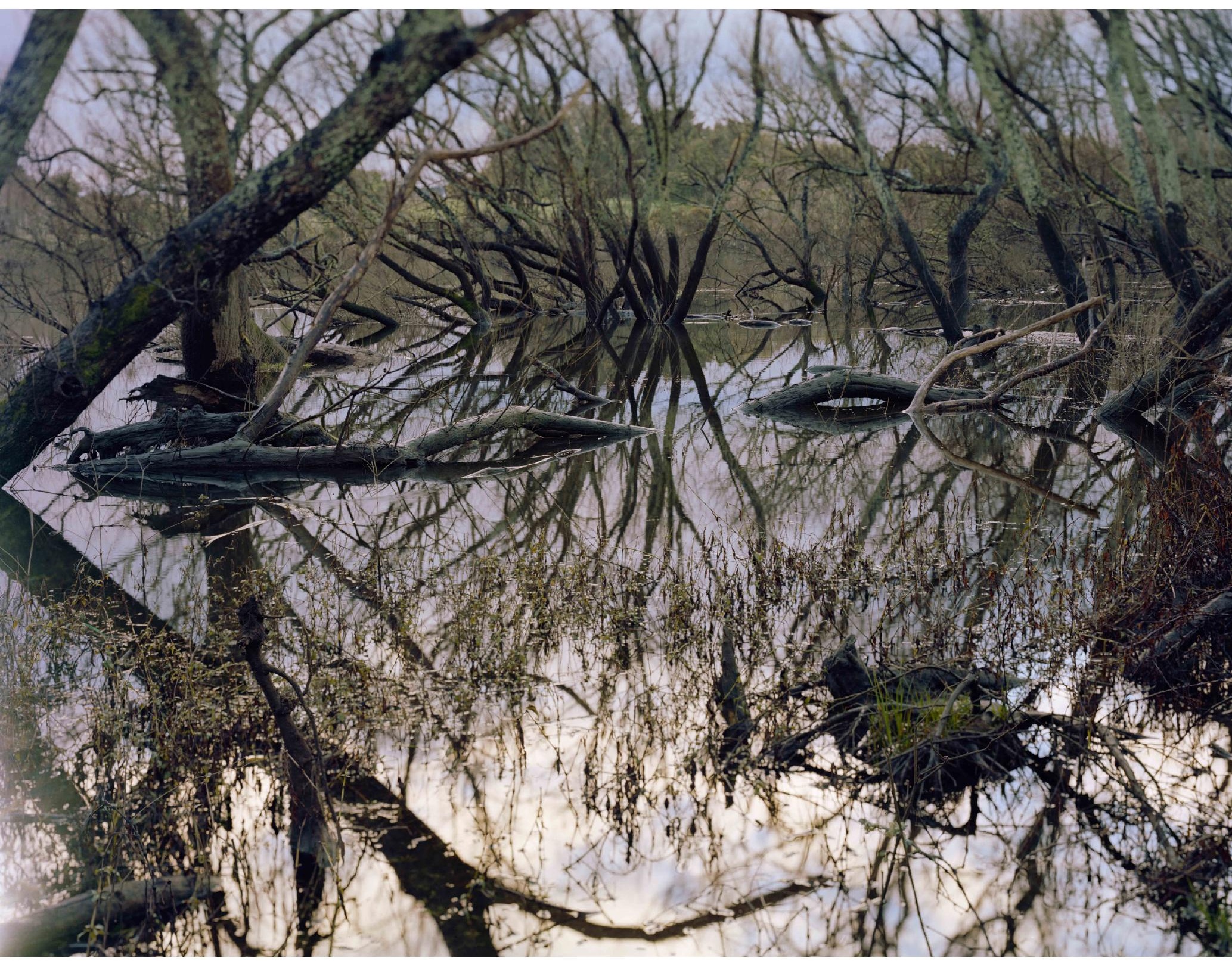

Fig 5. Waikato River, Ngāruawāhia 


\section{Conclusion}

My photography practice and iterative methodology comprised a model through which place can be perceived and represented. This model can also be understood as an artistic methodology of place-making. Within this context, my photography practice became a fluid multimodal practice of representation, advancing into a territory where artistic expression prevailed through a project of loose but purposeful field approach-encounters.

The production of creative milestones generated rigorous critical analysis of my creative processes and photography practice. In a sense the four creative milestones may be interpreted as a form of research findings focused on processes and generated creative products. The iteration of methods and production of creative milestones offered a model through which artists from an array of disciplines can explore a range of subjects including my focus on place, place imaginaries and place-making. My focus, therefore, was not only on the act of making photographs, but also on the possibilities for sense-making embedded into forms of curation and production of creative milestones. These ideas extend to the act of making into articulated forms of sense-making connected to conceptual argumentation.

I therefore acknowledge my artistic practice as a heuristic form of inquiry and critical thinking through making. In addition I reiterate the idea of carving ones own methodology as a complex set of methods aimed at specific research approaches. The leap from objective to contemporary approaches to photography must be considered in order to generate further routes to knowledge production and ways of interpreting meanings. Qualitative research approaches to visual research informed by contemporary photography practice allow lens-based artists to expand their practices, moving away from the idea of photography as a mere tool to record reality. In this context, qualitative lens-based practitioners have the opportunity of entering into stimulating research territories of possibilities where further views and meanings can be catalysed. 


\section{References}

Berger, J. (1980). About Looking. Writers and Readers Publishing Cooperative, LTD.

Bergson, H. (1911). Matter and memory. George Allen.

Bergson, H. (2001). Creative evolution. Electric Book Co. http://site.ebrary.com

Bishop, C. (2005). Installation art: A critical history. Tate.

Boast, R., \& Hill, R. S. (Eds.). (2009). Raupatu: The confiscation of Māori land. Victoria University Press.

Butt, D. (2017). Artistic Research in the Future Academy. Intellect.

Celant, G. (1996). A visual machine. Art installations and its modern archetypes. In R. Greenberg, B. W. Ferguson, \& S. Nairne (Eds.), Thinking about exhibitions (pp. 371-386). Routledge.

De Oliveira, N., Oxley, N., \& Petry, M. (2006). Installation art in the new millennium: The empire of the senses. Thames \& Hudson.

Deleuze, G. (1988). Bergsonism. Zone Books.

Deleuze, G. (1989). Cinema 2: The time-image. University of Minnesota Press. https://monoskop.org/images/6/68/Deleuze_Gilles_Cinema_2_Time-Image.pdf

Deleuze, G., \& Guattari, F. (1994). What is philosophy? (G. Burchell \& H. Tomlinson, Trans.). Verso. Egert, G. (2016). Barbara Glowczewski, Totemic Becomings. Cosmopolitics of the Dreaming. Book Review. Anthrovision. Vaneasa Online Journal, 4.1. http://anthrovision.revues. org/2291

Fisher, M. (2016). 'I riro whenua atu me hoki whenua mai': The return of land and the Waikato-Tainui raupatu settlement. Journal of New Zealand Studies, 23, 19-36.

Hill, R. (2019). Place imaginaries: Photography and place-making at Te Awa River Ride [Thesis, The University of Waikato]. https://researchcommons.waikato.ac.nz/handle/10289/12797 Hill, R. (2020). Post-photography: Lens-based methodology and practice-led ways of critical thinking. In Link Symposium Abstracts 2020 (pp. 28-29)

King, C. M., \& Roa, T. om. (2015). The Maori of the Central North Island before 1860. In C. M. King, D. J. Gaukrodger, \& N. A. Ritchie (Eds.), The drama of conservation: The history of the Pureora Forest, New Zealand (pp. 43-66). Department of Conservation, NZ \& Springer International. https://doi.org/10.1007/978-3-319-18410-4_3

King, M. (2013). Te Puea: A life. https://www.overdrive.com/search?q=C275DBBF-A11C-4FAB-A5C7-AD53E410D0AA

Köhler, M. (Ed.). (1989). Constructed realities: The art of staged photography. Edition Stemmle.

Leavy, P. (2014). Method meets art: Arts-based research practice (2nd ed.). The Guilford Press. http://site.ebrary.com/lib/alltitles/docDetail.action?docID=11001927

Massey, D. B., Allen, J., \& Sarre, P. (Eds.). (2007). Human geography today. Polity Press.

Muru-Lanning, M. (2016). Tupuna Awa: People and politics of the Waikato River. Auckland University Press.

Sonn, C. C., Quayle, A. F., \& Kasat, P. (2015). Picturing the wheatbelt: Exploring and expressing place identity through photography. American Journal of Community Psychology, 55(1-2), 89-101. https://doi.org/10.1007/s10464-014-9686-7

Waikato Raupatu Lands Trust. (2008). Waikato Raupatu River Settlement: Information package, August 2008. Author.

Recebido: 03 de março de 2021.

Aprovado: 12 de abril de 2021. 